\title{
Effect of Constructivist Teaching Approach on Students' Achievement in Mathematics at Secondary School Level
}

\author{
Syeda Khaja Mohsina Banu"1, Prof. Siddiqui Mohd Mahmood ${ }^{2}$
}

${ }^{1}$ Ph.D. Scholar, Department of Education and Training, Maulana Azad National Urdu University, Hyderabad, Telangana, India

2Professor, Department of Education and Training, Maulana Azad National Urdu University, Hyderabad, Telangana, India

\begin{abstract}
This paper outlines an experimental study on students learning in a constructivist environment and its subsequent effect on achievement in mathematics at the secondary level of learners. The study aims to know the effect of a constructivist teaching approach in mathematics achievement of grade 9th students belong to a secondary school of Warangal Urban district. The research is experimental in nature; pre-test post-test group design is selected for this purpose. 5E's learning (Engage-Explore-Explain-Elaborate-Evaluate) strategy has been applied to the experimental group and transmission method of teaching followed by a control group where the total 64 (32 control group and 32 experimental group) students participated. Pre-test in mathematics achievement was conducted for both groups prior to the treatment. Experimental group students were taught through constructivist teaching approach whereas the control group students were taught through transmission approach and the post-test was conducted after the treatment. The mathematics achievement test (MAT) was used to evaluate the students' achievement from both groups. On the basis of statistical measures, $\mathrm{t}$-values and effect sizes were calculated to find the significant differences between the groups. The analysis of data showed that on the entire, experimental group performed better than the control group. Thus the final results of the study indicated that experimental group students' performance improved after treatment whereas the control group did not show any improvement.
\end{abstract}

Keywords : Constructivist Teaching Method, Transmission Teaching Method, Achievement in Mathematics.

\section{INTRODUCTION}

Constructivism is an emerging pedagogy among the teaching community across the world and National Curriculum Framework (NCF 2005) confirmed the direction to it in Indian classroom situation (Dr. Rajender Kumar Nayak,2011). It is a view of learning based on the belief that knowledge is not a thing that can be simply given by the teacher inside the class room to the students on their desk. Rather, knowledge is constructed by students through an active mental process of development; students are the builders and creators of meaning and knowledge (K. V. Sridevi, 2008).
A constructivist teacher offers his/her students options and choices in their work, rejecting the common practice of telling students what to do, he/she engages their trust and invites them to participate in a constructivist process that allows them to be involved in decisions about their learning. Students actively involved in their own learning are a vital reality in constructivist class rooms. Students may participate in the design of their assignments, although the parameters for these may be established by their teacher. 
Constructivist teacher encourages learners to constantly assess how the activity is helping them gain understanding by questioning themselves and their strategies (Kenneth D. Moore, Jacqueline Hansen 2011). Learners in the constructivist class room ideally become "Expert Learners." This gives them ever broadening tools to keep learning with a well-planned class room environment, the students learn "How to Learn."

\subsection{TRANSMISSION APPROACH}

A transmission approach is rooted in the belief that the primary purpose of education is to induct young people into the established values, belief and accepted knowledge of the existing society or community.

The transmission instructional model is a teachercentered teaching and learning model in which the teacher's role is to design lessons aimed at predetermined goals and to present knowledge and skills in a predetermined order, and students' tasks are to passively acquire teacher-specified knowledge and skills (Guzzetti, 2002; Arends, 2012; Slavin, 2012).

\subsubsection{CHARACTERISTICS OF TRANSMISSION APPROACH}

It is a teacher-centred approach in which teacher is the dispenser of knowledge, the arbitrator of truth and the final evaluator of learning

$>$ In transmission perspective, teaching is the act of transmitting knowledge from teacher to student

$>$ The main responsibility of the teacher is to represent the content correctly and efficiently.

From this perspective a teacher's job is to supply students with a designated body of knowledge in a predetermined order.
$>$ It is the most common orientation to teaching in elementary, secondary and higher education used in India.

Teacher transmits information to students, who are expected to absorb, memorise, or otherwise master the material they are taught.

From the above discussion we can say that the transmission approach is a teacher-centred approach, students are the receivers of knowledge. In this teacher tries to transmit knowledge in a predetermined order and students' jobs are to passively acquire teacher's transmitted knowledge and of course teacher is the final evaluator of learning.

\subsection{COMMON DIFFICULTIES OF TRANSMISSION APPROACH}

Teachers whose dominant perspective is transmission may experience some difficulties. Pratt (1999) has summarizes with brevity. These related to;

$>$ Adjusting to individual differences of students

$>$ Predicting where (in content) and why learners will have difficulty.

$>$ Following this approach when teaching on "illstructured parts of a task or problem, e.g., where there is more than one acceptable answer or way of thinking.

$>$ Working with students who cannot understand the content.

> Using materials from "real world" outside the class room

$>$ Primary focus on content rather than the students

\subsection{CONSTRUCTIVIST TEACHING APPROACH}

\subsubsection{Meaning and Definition of Constructivist teaching}

The verb "to construct" is derived from the Latin word 'CONSTRUER' which means to arrange or to 
give structure, ongoing structuring (Organizing) process" (Narang, 2013).

Constructivism means construction of knowledge in which the learners actively construct their own knowledge by linking new information to their existing knowledge on the basis of materials presented to them (experience) (Khadar, 2015).

Constructivist teaching ideas are used in developing the educational standards in United States. Its use in teaching is highly recommended in European countries also constructivist approach to learning and teaching has increasingly become influential over the past few decades and attention has increasingly focused on how we learn and what we learn (Dowing, 2010).

The constructivist offers a sharp contrast view to the transmission perspective. The basic tenets of constructivism are that knowledge, instead of being objective and fixed, is personal, social, and cultural and that knowledge is actively created by the learner, not passively received from the environment (Clements and Battista, 1990; Arends, 2012). In the student-centered constructivist instructional model, teachers establish conditions for student inquiry, involve students in planning, accept students' ideas, and provide them with autonomy and choice; students interact with others and actively participate in investigations and problem-solving activities (Savery and Duffy, 1994; Arends, 2012; Slavin, 2012).

\subsection{FEATURES OF CONSTRUCTIVIST TEACHING ACCORDING TO NCF-2005}

National Curriculum frame work (NCF-2005) proposed a paradigm shift to constructivism in schooling. NCF-2005 has given impetus to the constructivist approach to teaching-learning as constructivism stated assuming greater importance in contemporary psychology and epistemology as growing relevance in pedagogy and schooling. However, constructivism as an all-encompassing approach used by Philosophies, psychologists, curriculum designers, educators and pedagogues to meaning making needs to be probed in order to develop awareness among actual class room practitioners.

Following are the important constructivist pedagogical practices listed in NCF-2005:

1. In constructivist view, learning process emphasizes on construction of knowledge

2. Students interact with material and experiences provided by the teachers to construct their knowledge in the background of prior knowledge.

3. Structuring and restructuring ideas lead to progress in students learning process.

4. Students construct their mental images of relationship i.e., cause and effect relationship through relevant activities.

5. Knowledge construction is also a social process. In true sense, complex knowledge situated in group and needs collaborative learning to enable the students to engage in discussion of meaning, sharing of multiple views and to change their internal representation of external reality.

6. Students construct their knowledge individually as well as socially ( $\mathrm{Pal}, 2005)$.

\subsection{Teaching Mathematics in Secondary Schools Through Constructivist Approach}

Secondary school mathematics introduces the child to a world of new language, new symbols and a more abstract subject. Number concepts become more generalized and the introduction of geometry tests the students' spatial awareness. The subject becomes more distant from everyday number manipulation 
and real life problems. The content of the mathematics curriculum is full and varied and the time allocated to transmitting this content is often limited. (Peter Leonard Hawkey, 1995)

Mathematics teaching is no longer simply transmitting a body of knowledge but rather the creating of desirable learning situations which facilitate the students' access to knowledge.

Teaching at secondary school must provide attention to the affective variables associated with mathematics. The classroom atmosphere and providing positive mathematical experiences are the cornerstones of providing a base in which students at different levels may all reach their full potential.

A much heralded alternative is to change the focus of the classroom from teacher centered to studentcentred using a Constructivist Approach. Constructivist teaching practices in Mathematics classrooms are intended to produce much more challenging instructions for students and thus, produce improved meaningful learning. These changes have led to instruction in which students are expected to contribute actively to mathematics lessons by explaining their mathematical reasoning to each other and constructing their own understanding of mathematical concepts.

Constructivist teaching in Mathematics believes that student can construct knowledge by active participation rather than acquiring knowledge by teachers' demonstration in the classroom and, to learn to speak, think and act mathematically participating in Mathematical discussion and solving new problems.

\subsection{OBJECTIVE OF THE STUDY}

The present study has the following objectives;

1. To compare the mean scores of mathematics achievementin Pre-Tests of Experimental Group and Control Group.

2. To compare the mean scores of mathematics achievementin Pre-test and Post-Test of Experimental Group.

3. To compare the mean scores of mathematics achievement in Post-Tests of Experimental Group and Control Group.

4. To compare the mean scores of mathematics achievementin Pre-test and Post-Test of Control Group.

\subsection{HYPOTHESES}

1. There is no significant difference betweenmean scores of mathematics achievement in Pre-Tests of Experimental Group and Control Group.

2. There is no significant difference between mean scores of mathematics achievement in Pre-test and Post-Test of Experimental Group.

3. There is no significant difference between mean scores of mathematics achievement in Post-Tests of Experimental Group and Control Group.

4. There is no significant difference between mean scores of mathematics achievementin Pre-test and Post-Test of Control Group.

\subsection{VARIABLES INCLUDED IN THE STUDY}

1.8.1 Independent Variable: Constructivist Teaching Approach

1.8.2 Dependent Variable : Academic Achievement

\section{REVIEW OF RELATED LITERATURE:}


The review of literature reveals that current educational system requires a shift from the traditional teaching approach to a constructivist teaching approach. A lot of theories are available on constructivism but very limited studies were found on constructivist teaching approach in Secondary School Mathematics.

During most recent years, the researches in the area of Constructivist approach, its importance, implications in education and its role in achievement have proved their importance in the field of education. Therefore, the researcher also took study in this area. In the previous researches, various variables have been studied to see their relations with constructivism. Among them sex, age, study skills, mental ability, culture, self-efficacy, stream, instructional design, personality, were studied more frequently. In the present study the researcher is seen the subsequent effect of Constructivist teaching approach on students', Learning Strategies and Academic Achievement in Mathematics.

\section{RESEARCH METHODOLOGY}

The present study is an experimental research method. The design adopted in the study is a quasiexperimental, which is different from true experimental design. In this study, research tools are developed to obtain the data.

\subsection{Research Design}

The following is a research outline of the current study

\section{Sample of the Study:}

The intact groups of $649^{\text {th }}$ class students including both experimental and control group are taken up for the study. The sample included 32 boys and 32 girls in total.

\begin{tabular}{|l|c|c|c|}
\hline Sample & Boys & Girls & Total \\
\hline $\begin{array}{l}\text { Experimental } \\
\text { Group }\end{array}$ & 16 & 16 & 32 \\
\hline Control Group & 16 & 16 & 32 \\
\hline Total & 32 & 32 & 64 \\
\hline
\end{tabular}

The researcher has adopted the purposive sampling method; Shine High School of Warangal Urban is purposively selected to conduct the research of the study. Selected students are divided into two groups namely, experimental and Control Group by simple random sampling techniques. In each group 32 and 32 students are included as a sample. Pre-tests are administered on a specified syllabus of $9^{\text {th }}$ class Mathematics, and Learning Strategies prior to commencement of experiment. After pre-tests experimental group was given a treatment and posttest conducted for both the groups. Which can be understood from the following Group Diagram.

\begin{tabular}{|ccc|}
\hline Pre-test & Treatment & Post-test \\
O1 & $\mathrm{X} 1$ & $\mathrm{O} 2$ \\
O3 & $\mathrm{X} 2$ & $\mathrm{O} 4$ \\
\hline
\end{tabular}

Where,

O1 O3: Pre-test of academic achievement.

O2 O4: Post-test of academic achievement.

X1: constructivist Teaching

X2: Transmission Teaching

\subsection{Tools of The Study}

To study the effectiveness of constructivist teaching approach on the dependant variable i.e. achievement test in mathematics consist of 60 MCQs was prepared by the researcher is used. The reliability of the test was 0.79 . 


\section{IMPLEMENTATION OF EXPERIMENT}

The instructional materials developed were implemented to the experimental group for a period of 3 months. On parlance with this, Mathematics teacher of control group was consulted regarding the duration i.e. number of periods required for teaching the selected chapters, mode of teaching and assessment that she would follow in that group.

The researcher has taught 4 Chapters (i.e. linear equation with two variables, the elements of geometry, statistics, surface areas and volumes) using constructivist approach to the students of experimental group, preceded by systematically planned and formatted daily lessons based on constructivist principles. The classes were taken in the daily mathematics periods of the school. In the control group, regular mathematics teacher taught the students and covered the selected chapters approximately in the same number of periods.

In the experimental group, the researcher created such an environment in the classroom that the students were able to construct the knowledge related to the given concepts and themes by doing various activities in which already known experiences and previous knowledge played a significant role. The researcher got continuous feedback from the experimental group students and their regular teachers. Based on their feedback, necessary modifications were made time to time. The post tests were conducted upon teaching completion of selected chapters through constructivist teaching approach.

\subsection{Use of Statistical Techniques}

Statistical techniques have a very important role to play in analysing and interpreting and achieving the results. The selection of the statistical technique depends on the nature of the research. The researcher used the following statistical techniques to analyse and interpret the obtained data, keeping in view the nature of the research.

1. Mean.

2. Standard Deviation.

3. $\mathrm{t}$-Test.

4. Effect Size (Cohen's d).

\section{ANALYSIS, INTERPRETATION AND RESULTS OF STUDY}

Objective 1 : To compare the mean scores of mathematics achievement in Pre-Tests of Experimental Group and Control Group.

Hypothesis 1 : There is no significant difference between mean scores of mathematics achievement in Pre-Tests of Experimental Group and Control Group.

Pre-test was conducted in order to determine the students' achievement in Mathematics prior to the treatment.

Table 4.1 : Comparison between Pre-tests of control group and experimental group Achievement of Mathematics

\begin{tabular}{|c|c|c|c|c|c|c|}
\hline $\begin{array}{l}\text { Pre-test } \\
\text { Groups }\end{array}$ & $\mathbf{N}$ & $\begin{array}{c}\text { Mea } \\
\mathbf{n}\end{array}$ & Sd & Df & $\begin{array}{c}\text { Obta } \\
\text { ined } \\
\mathrm{t}- \\
\text { Valu } \\
\text { e }\end{array}$ & $\begin{array}{c}\text { Effe } \\
\text { ct } \\
\text { Size }\end{array}$ \\
\hline $\begin{array}{l}\text { Control } \\
\text { Group }\end{array}$ & 32 & 39.65 & 4.95 & \multirow{2}{*}{62} & \multirow{2}{*}{0.86} & \multirow{2}{*}{0.22} \\
\hline $\begin{array}{l}\text { Experimenta } \\
1 \text { Group }\end{array}$ & 32 & 40.96 & 7.12 & & & \\
\hline
\end{tabular}

The above table 4.1 shows the mean scores of control group and experimental group are 39.652and 
40.969respectively. The calculated t-value is 0.86 , which is notsignificant at both the level. Hence, the null hypothesis is accepted. Which says that there is no significant difference between mean scores of mathematics achievement in Pre-Tests of Experimental Group and Control Group.The effect size (Cohen's d) found out between experimental group and control group is 0.22 which indicates the small effect size.

Objective 2: To compare the mean scores of mathematics achievement in Pre-test and Post-Test of Experimental Group.

Hypothesis 2:There is no significant difference between mean scores of mathematics achievement in Pre-test and Post-Test of Experimental Group.

Pre-test and post-test were conducted in order to determine the achievement in mathematics of experimental group students before and after the treatment.

Table 4.2 : Comparison between Pre-test and posttest of Experimental Group Achievement in Mathematics

\begin{tabular}{|c|c|c|c|c|c|c|}
\hline $\begin{array}{c}\text { Experiment } \\
\text { al Group }\end{array}$ & N & $\begin{array}{c}\text { Mea } \\
\text { n }\end{array}$ & Sd & $\begin{array}{c}\text { D } \\
\text { f }\end{array}$ & $\begin{array}{c}\text { Obtaine } \\
\mathbf{d} \\
\text { t-Value }\end{array}$ & $\begin{array}{c}\text { Effec } \\
\text { Size }\end{array}$ \\
\hline Pre-Test & 3 & 40.9 & 7.1 & & & \\
\hline Post-Test & 2 & 6 & 2 & 3 & 7.28 & 1.82 \\
& 2 & 1 & 7 & & & \\
\hline
\end{tabular}

The above table 4.2 shows the mean scores of experimental group are 40.96 and 50.71 respectively. It is further indicated that the obtained $t$ - value is 7.28 which is significant at both levels, indicating there by a significant difference in pre-test and posttest of experimental group achievement in Mathematics.Hence, the null hypothesis is rejected, which says that there is no significant difference between mean scores of mathematics achievement in Pre-test and Post-Test of Experimental Group.The effect size (Cohen's d) found out between experimental group and control group is 1.82 which indicates the large effect size.

Objective 3: To compare the mean scores of mathematics achievement in Post-Tests of Experimental Group and Control Group.

Hypothesis3:There is no significant difference between mean scores of mathematics achievement in Post-Tests of Experimental Group and Control Group.

Post-test was conducted in order to determine the achievement in mathematics of experimental and control groups after the treatment.

Table 4.3 : Comparison between Post-tests of control group and experimental group Achievement in Mathematics

\begin{tabular}{|l|c|c|c|c|c|c|}
\hline \multicolumn{1}{|c|}{$\begin{array}{c}\text { Post Test } \\
\text { Groups }\end{array}$} & N & $\begin{array}{c}\text { Mea } \\
\mathbf{n}\end{array}$ & Sd & $\begin{array}{c}\text { D } \\
\mathbf{f}\end{array}$ & $\begin{array}{c}\text { Obtaine } \\
\mathbf{d} \\
\text { T- } \\
\text { Value }\end{array}$ & $\begin{array}{c}\text { Effec } \\
\mathbf{t} \\
\text { Size }\end{array}$ \\
\hline $\begin{array}{l}\text { Experiment } \\
\text { al Group }\end{array}$ & 3 & 50.7 & 2.5 & & & \\
\hline $\begin{array}{l}\text { Control } \\
\text { Group }\end{array}$ & 3 & 41.9 & 7.1 & 2 & 6.54 & 1.64 \\
\hline
\end{tabular}

The above table 4.3 shows the mean scores of control group and experimental group are 41.90 and 50.71 respectively. The calculated t-value is 6.54 , which issignificant at both the level. Hence, the null hypothesis is rejected,which says that There is no significant difference between mean scores of mathematics achievement in Post-Tests of Experimental Group and Control Group. The effect size (Cohen's d) found out between experimental group and control group is 1.64 which indicates the large effect size. 
Objective 4: To compare the mean scores of mathematics achievement in Pre-test and Post-Test of Control Group.

Hypothesis 4: There is no significant difference between mean scores of mathematics achievement in Pre-test and Post-Test of Control Group.

Pre-test and post-test were conducted in order to determine the achievement in Mathematics of control group.

Table 4.4 : Comparison between Pre and Post-tests of control group Achievement of Mathematics

\begin{tabular}{|l|c|c|c|c|c|c|}
\hline $\begin{array}{l}\text { Control } \\
\text { Group }\end{array}$ & N & Mean & Sd & Df & $\begin{array}{c}\text { Obtained } \\
\text { t-Value }\end{array}$ & $\begin{array}{c}\text { Effect } \\
\text { Size }\end{array}$ \\
\hline $\begin{array}{l}\text { Pre } \\
\text { Test }\end{array}$ & 32 & 39.65 & 4.95 & & & \\
\hline $\begin{array}{l}\text { Post } \\
\text { Test }\end{array}$ & 32 & 41.90 & 7.16 & & 1.46 & 0.37 \\
\hline
\end{tabular}

The above table 4.4 shows the mean scores of control group are 39.65 and 41.90 respectively. It is further indicated that the obtained $\mathrm{t}$ - value is 1.46 which is not significant at both levels, indicating there by no significant difference in pre-test and post-test of control group achievement in Mathematics.Hence, the null hypothesis is accepted, which says that there is no significant difference between mean scores of mathematics achievement in Pre-test and Post-Test of Control Group. The effect size (Cohen's d) found out between experimental group and control group is 0.37 which indicates the medium effect size.

\section{SUMMARY OF THE FINDINGS}

The students who belong to the experimental group significantly have better achievement in mathematics than those students who belong to the control group. consequently, students become the constructor of knowledge.

\section{v. CONCLUSION}

The present study investigated the effect of constructivist teaching approach on students' achievement in mathematics at secondary school level. The results further indicated that there has been significantly large effect of constructivist teaching approach onstudents'achievement in mathematics of experimental group ascompared to the students of control group.

\section{REFERENCES}

[1] J. G., \& Brooks, M. G. (1993). In Search of Understanding: The Case for Constructivist

[2] Christie, A. (2005). Constructivism and its implications for educators. http://alicechristie.com/edtech/learning/constructivis $\mathrm{m} / \mathrm{index} \cdot \mathrm{htm}$

[3] Sharma, S. (2006). Constructivist Approaches to Teaching and learning. NCERT: New Delhi.

[4] Swan, K. (2005). A constructivist model for thinking about learning online. In J. Bourne \& J. C.

[5] Kim, J.K (2005).The Effect of a Constructivist Teaching Approach on Student Academic Achievement, Self concepts and leaning strategies. Asia Pacific Education Review. 6(1), 7-19

[6] Krosbbrgen \&Vanluit (2005). Constructivist Mathematics Education for Students with Mild Mental Retardation. European Journal of Special Needs Education, 20(1), 107-116.

[7] Harikrishnan. M, Firdose; International Journal of Advance Research, Ideas and Innovations in Technology, A Study on the Constructive based Teaching Strategies in Relation to Academic Achievement in English (2018), 573-578.

Cite this article as : Syeda Khaja Mohsina Banu, Prof. Siddiqui Mohd Mahmood, "Effect of Constructivist Teaching Approach on Students' Achievement in Mathematics at Secondary School Level", International Journal of Scientific Research in Science and Technology (IJSRST), Online ISSN : 2395-602X, Print ISSN : 2395-6011, Volume 6 Issue 3, pp. 362-369, May-June 2019. Available at doi : https://doi.org/10.32628/IJSRST207253 Journal URL : http://ijsrst.com/IJSRST207253 